\title{
Exploring Authentic Leadership in relation to Followers' Authentic Leadership Development in Public and Private Sector Universities
}

\author{
* Dr. Said Saeed, Principal \\ ** Dr. Riasat Ali, Professor \\ *** Dr. Fazli Khaliq, SST
}

\begin{abstract}
The study aims to explore the authentic leadership attributes (ALA) and its impact on the followers' authentic leadership development (FALD). The objectives of the study were to investigate authentic leadership attributes of leaders, find out existing position of followers' authentic leadership development and measure relationship between authentic leadership attributes and followers' authentic leadership development at university level. The population of the study was 6975. The sample of the study was 967. The mixed method approach was used to collect information from the sample through modified form of $A L Q$ developed by Walumbwa, Avolio, Gardener, Wernsing, \& Peterson (2008) and in-depth interviews. Analysis was done with Mean, STD deviation, Pearson's rank correlation and thematic analysis. It was found that $r$ value (.513) which was significant at .000 showed significant positive large correlations between authentic leadership attributes and followers' authentic leadership development at university level.
\end{abstract}

Keywords: Leadership, Authentic Leadership Attributes, Followers' Authentic Leadership Development

\section{Introduction}

Authentic leadership is the outcome of the refinement of notions relating to leadership and appeared as thought-provoking management model. Scholars like Gardner, Avolio and Walumbwa (2005) were of the opinion that AL is the combining of high intellectual abilities and administrative commitment which become the means of creating the fundamental constituents of authentic leadership. Authentic leadership theory (ALT) is in embryonic stage and needs the due concentration of the researchers to know how to bring the spirit of fair dealings in all kinds of managerial matters (Zhang, Everett, Elkin, \& Cone, 2012).

\footnotetext{
* Elementary \& Secondary Education Department Khyber Pakhtunkhwa. Email: syedsaeed54@ gmail.com

** Department of Education, Abdul Wali Khan University Mardan. Email: riasat@awkum.edu.pk

*** Elementary \& Secondary Education Department Khyber Pakhtunkhwa. Email: khaliq78@ yahoo.com
} 
Authentic leaders having relational transparency, idealized influence, ethical perspective, knowledge generation, self-awareness, balanced processing information, openness and fairness, integrity, objectivity, trust, honesty, leader-followers interaction, followers-centric in place of leader-centric attitude, collaborative and collective learning, truthfulness, kind attitude, generosity, and true self will bring development in organization for the achievement of organizational outcomes through human resources and to help them lead, and also that they can model its use for others. Authentic leadership will cause organizations to collect, manipulate, observe, and report innovative and diverse kinds of organizational achievement and growth data; leaders will have to be adroit and proficient in doing this (Gardner et al, 2005). Followers' development is the main area of authentic leadership. There is a significant relationship between authentic leadership and followers' development (Emuwa, 2013).

\section{Statement of the Problem}

The new millennium in Pakistan is shocking and dismal for many people due to the unethical practices in all walks of life. The society is feeling thirst for a new brand of leaders who epitomize an understanding and cognizance of aim and show loyalty to beliefs and ethics (Ahmed, Shad, Mumtaz, \& Tanveer, 2012). Watts (2015) suggested that people require leaders who are the symbols of principles and straightforwardness; and who are the nice agents of the heritage left by their forerunners. All around us, the ideas, signals and symbols are understood that organizational leaders must meet the truth of decreasing optimism, poise, hopefulness, confidence and self- assurance in themselves and in their members (Tapara, 2011).

The main objective of this study is to investigate the attributes of authentic leadership and its relationship with followers' authentic leadership development at university level. The previous research works have shown that authenticity and authentic leadership have positive influences on the performance of the human resources, particularly on followers' authentic leadership development. Authentic leadership attributes play crucial importance in teachers' professional development and in making future leaders.

\section{Objectives of the Study}

The objectives of the study were;

1) To investigate authentic leadership attributes of educational leaders at university level

2) To investigate the existing status of followers' authentic leadership development at university level 
3) To measure relationship between authentic leadership attributes and followers' authentic leadership development in public and private sector universities

\section{Research Questions}

1. What are authentic leadership attributes of educational leaders at university level?

2. What is the existing status of followers' authentic leadership development as organizational development at university level?

3. Is there a relationship between authentic leadership attributes and followers' authentic leadership development in public and private sector universities?

\section{Literature Review}

AL appeared as a fruit of the previous leadership notions. It has universality. As organizations develop, so problems created. The best weapon to handle such type of situation in academic institutions is AL (Gardner et al., 2005). Leaders in academic circles are the forefront workforce (Watt, 2015), properly grooming the next generation to face lurking challenges and intricacies of the time.

Different empirical studies showed the variables of AL i.e. self-awareness (SA), relational transparency (RT), ethical perspective (EP), balance processing information- BPI (Walumbwa et al., 2008), positive psychological capital, self-truth and authenticity (Rego et al, 2013) as well as diverse components of organizational development, org. effectiveness, communication, behaviour, psychological capital, work engagement, pedagogical development, followers' authentic leadership development, classroom management, professional development trainings, followers' leader interaction, and followers' AL development.

Authentic leadership (ALs) is a gathering of self-information, understanding and thoughtfulness to the positioning of other people and a methodological cleverness that proceeds to the interaction of leadership actions (Bento \& Ribeiro, 2013). Authentic leader is always cognizant of his natural abilities, recognizes his/her shortcomings and works hard to overcome these loopholes. He/she is dedicated to develop himself/herself because he is aware to become AL, it takes time. He /she is believed by co-workers, true and a man of ethical attractiveness and ethical purpose. He/she establishes direct relationship with followers for bringing improvement in organizational structure and its values (Luthans \& Youssef, 2007).

ALs is still at its nascent phase of evolution and displays some weaknesses in connection to validity and reliability of $\mathrm{AL}$ constructs and researchers are required to bring into consideration the positive and non-positive aspects of AL (Avolio, Walumbwa \& Weber, 
2009). Context or identity, without taking into consideration, is a weakness of AL, therefore, it is sought to explore through the lived experiences of participants that scrutinize the setting based on environments affects numerous individualities (Jones, Kim, \& Skendall, 2012). In addition, the ethical aspect and criteria of information, has not been completely illuminated (Northouse, 2013).

ALs produces significant transformation in the life of individuals; organization, discernment and principles are reshaped; prospects and ambitions of followers are changed; leader's personality is valued; role model is made for ethical development; vision is energized; and goals are faced (Kotlyar \& Karakowsky, 2007).

AL theory says that leaders must display the crucial constituents-relational transparency (RT), self-awareness (SA), ethical perspective (EP), authentic behavior (AB), positive psychological capital (PPC) and balance processing of information (BPI) of ALs to lead efficiently and successfully (Walumbwa et al., 2008). Avolio and Gardner (2005) reported that ALs is the epitome of self-awareness and principles; honesty and transparency in judgments.

AL is self-identity, self-knowing, followers-knowing, world-knowing and Godknowing. AL is showing truth and feeling fair in his/her dealing with others (George, 2003). AL is all-encompassing and inclusive of both transformational and transactional leadership styles (Avolio \& Gardner, 2005).

The authentic leaders have distinguishing qualities of influencing the followers in a way that enhance the feeling of assurance, devotion, enthusiasm, keenness, perseverance, allegiance, staunchness and inspiring to progress the responsibilities accomplished in the organization perpetually (Avolio, et al., 2004). Ethics and morality of the leader are the crucial components of AL theory (Hester, \& Killian, 2011).

ALs is a procedure of adapting self-awareness, self-regulation in constructive attitudes by both leaders and followers which result an encouraging development of self and others' aptitudes of sanguinity, brightness, pliability, malleability, flexibility, confidence, coolness, poise, dignity and calmness (Sparrowe, 2005). Furthermore, Ilies et al. (2005) advocated Kernis' (2003) ALs model, mixture of four behaviours- neutral dispensation, selfconsciousness, reliable interactive placement and true conduct. Similarly, Shamir and Eilam (2005) reported that authentic leader is the mirror of intelligibility of self-concept, selfagreement aims and goals, and self- expressive behaviour. 
Additionally, ALs notion is at the embryonic phases of paradigm (Walumbwa et al., 2010). Nevertheless, genuineness concept has it origin in the discipline of psychology (Kernis, 2003) and philosophy (Harter, 2002). Similarly, in current years, authenticity construct was polished and illuminated by experiential studies. All-inclusive studies progressed progressive idea, indicated persons' confession of flaws as well as strong points at tremendous scale (Humphreys et al., 2011). AL are broadminded personalities, having emancipation from self-justifying partialities in contrast to immature individuals. AL are translucent, crystal-clear and not immature persons. They display intimate interactions which mirror their genuine attributes, uniformity, philosophies, standards and activities. Moreover, Ryan and Deci (2003) discussed that those who are the symbols of morality, self-truth in opposition to briberies, exterior intimidations, prizes and societal hopes, rank or position, are authentic leaders. Authentic leaders are defined by the stability, uniformity and reliability of their actions in light of ethical perspective (Hsiung, 2012).

Huang and Luthans (2013) posit that ALs is the product of the aftermath of industrialized management theory, signifying that it is cooperative, interpersonal, and not concentrated on specific spearhead. Answers to organizational challenges and opportunities have been provided by authentic practices and AL theory, for institutional transformation, by admitting how their different and crisscrossing social individualities influence them. Narrative, reflection and other modes focus leaders to examine the roots of their morals, and activities; and to encourage followers (Chávez \& Sanlo, 2013).

The dominant notion behind ALs is SA that help in the improvement of authentic followers. They also focus on the good fortune of the followers (Avolio \& Gardner, 2005). Self-awareness is flexible, flowing, emerging attribute and background shapes individuality and individuality shapes background of a person, and this is the self-truth (Jones, Kim \& Skendall, 2012). Flexibility is the strong point of ALs that can be used independently and jointly with other theories of leadership (Avolio \& Gardner, 2005). Relational model is another strength which focus on the FALD, and that is not leader-centric (Helstad, \& Moller, 2013). Trustworthiness is another strong point of AL means to fill an stated shared necessity for truthful headship at an undefined period, and its progressive method means that anybody (leader or followers) can learn to exercise it, and thus, block up that vacuum (Northouse, 2014).

Balanced processing, internalized moral perspective, relational transparency, and selfawareness are the conceptual basis, have been branded by research studies for AL behavior 
(Gardner et al., 2005; Ilies et al., 2005; Walumbwa et al., 2008). Balanced processing is the objective analysis of all related information prior to final decision-making. Internalized moral perspective is characterized by the intrinsic ethical values and criteria of the attitude of leaders rather than by extrinsic influence of society, same age people as well as by organizational atmosphere (Gardner et al., 2005). Relational transparency is the name of individual's openness. The information are shared willingly with others and one's opinions and frame of mind is communicated with the group members (Walumbwa et al., 2010). As a final point, self-awareness is getting information that how the followers think about his leadership as well as to know the drives and purposes and to weigh his strong and weak points for the heightening of their authenticity and genuineness and efficiency, using both self-learning and replicated self-perception (Walumbwa, Peterson, Avolio, \& Hartnell, 2010). These paradigms have been advocated scientifically and are considered as the foundation for the validation and measurement of AL (Walumbwa et al., 2008; Walumbwa et al., 2010).

Teaching atmosphere of the current time has driven both intellectuals and researchers equally to admit the need for a more unpretentious practice of management (Avolio \& Gardner, 2005). The ways of manifestation of AL are countless, though, the concept is founded on self-truth and practice professed by followers as actual and unaffected (Shamir \& Eilam, 2005). ALs is a innovative notion and is an evolving sort in present time investigation (Luthans \& Avolio, 2003). Bass and Bass (2008) posit that ALs was branded by theoreticians investigating TL.

Shamir and Eilam (2005) offer a finer explanation of AL. Authentic leaders- follow their own actions, beliefs, and they self-motivated and do not depend on the expectations of others and do not cry for position or status. Additionally, their behavior is not the imitation of others, but honorably driven by their own ethics and principles. In this respect, ALs can be seen as an interpersonal progression, shaped both by leaders and followers.

Since the inception of sophisticated technology, fiscal pressures, transnational competition, organizational initiatives, and an ever-growing financial and ethical climate, leaders in both private and public sector universities are meeting a high degree of difficulty in the environment (Guerrero, Lapalme, \& Séguin, 2015; Pirannejad, 2013). There is struggle for skills across organizations; upholding workers' engagement is challenging; leaders can no longer depend on their authority to attain their targets (Francisco, Gonzales, \& Vargas, 2015; Lelchook, 2012). Their workforce also expects to be esteemed, appreciated and supported, and to see their leaders as models of truth. At the same time, leaders have to make hard 
decisions which sometimes go against the outlooks and principles of their followers (Rich, Lepine, \& Crawford, 2010). The atmosphere in organizations is progressively multifaceted and challenging, and some leaders are not succeeding to cope with it, as apparent by the number of organizations that continue to experience failings. Many leaders are struggling to develop organizations that can operate successfully within multifarious settings, while ensuring that their followers behave ethically (Nonaka \& Takeuchi, 2011). Leaders are as being 'climate engineers'; what they convey through their character, principles, philosophies, fondness and manners, leaves an influence on those they lead (Padilla, Hogan \& Kaiser, 2007).

Followers are empowered by such attributes for the true assessment of the proficiency and ethical position of their leaders' deeds (Walumbwa et al., 2010).

Followers' efficiency can be stirred and driven by AL (Walumbwa, Luthans, Avey, \& Oke, 2011). Followers are advanced and strengthened by their authentic leaders by revitalizing and energizing them with noble actions psychologically, ethically and morally that are contributing to their performance. The perspective of complementary congruity produces the question that whether the followers' performance is uniformly or differently affected or taking influence in different context and further elucidate that to what extent it is same and to what extent it is different as influenced by AL (Grant, Gino, \& Hofmann, 2011). The complementary congruity theory further suggests that the performance of the followers is influenced efficiently by the positive effect of the authentic leader. Particularly, the qualities and attributes of authentic leaders back and balance the required abilities and skills, for good performance of the followers (Luthans, Youssef, \& Avolio, 2007). ALs! Thy name is a relational process (Dasborough \& Ashkanasy, 2005). Previous studies show that the continuous connections and exchange of views of the leaders and followers with one another enhance the performance for the better achievement of organizational goals (Huang \& Luthans, 2013).

Avolio et al. (2004) examine that the performance of the followers is positively influenced by AL. Gardner et al. (2005) and Kernis (2003) studied that for the achievement of frankness and candidness; candor and straightforwardness in their associations with their followers, authentic leaders adopts their inner values and true principles in their attitude. Avolio and Gardner (2005) argue that crystal clear decision-making and role model presentation are the universal qualities of authentic leaders, and provide guidance to the followers. Moral attitude of authentic leaders makes the availability of showing straight ways 
to the companions due to their desirability and believability as starring role representatives (Wang et al., 2014).

Authentic Leaders upkeep the welfare of their followers, ensure availability of advice, shelter, positive response and information that they would otherwise have deficiency (Hsieh \& Dan-Shang Wang, 2015).

\section{Methodology}

The study was mixed method research in nature. It is the blend of numerical and nonnumerical methodologies in one study (Creswell, 2015). Concurrent triangulation design (Convergent Parallel design) was used.

\section{Population of the Study}

The population was all VCs/ Deans, HEC approved supervisors, heads of departments (HODs), and teaching faculty of public and private sector universities of Khyber Pakhtunkhwa. Gay and Mills (2011) posit about the dimensions and proportion of the population that may either target or accessible.

The human resources population of the study is presented. HEC website was visited for the identification of the available population in twenty nine (29) public and private sector universities of Khyber Pakhtunkhwa. Twnenty nine (29) vice chancellors / (58) Deans, four hundred and theirty two (432) HODs, seven hundred and seventy two (772) HEC approved supervisors; and five thousand, seven hundred and forty two (5742) assistant professors and lecturers comprised the population of the study.

\section{Sample of the Study}

Probability and non-probability sampling techniques were used for selection of sample. Simple random sampling techniques were adapted for selection of sample to get quantitative data. Purposive sampling techniques were adopted for selection of leaders and teachers for interviews to gain qualitative data. All the leaders, and teachers in Abdul Wali Khan University, University of Swat, University of Swabi, University of Malakand, Shaheed Benazir Bhutto university Dir, Bacha Khan university, Islamia College university, First Woman university (Shaheed Benazir Bhutto university Peshawar, University of Haripur, Abasyn University, Preston University, Qurtaba University and Northern University Khyber Pakhtunkhwa- Pakistan constituted the sample of the study.

Human resources sample comprised twelve (12 with 40\%) Vice Chancellors/ Deans, one hundred and ninety five (195 with 45\%) HODs, three hundred and fifty (350 with 45\%) HEC supervisors and four hundred and ten (410 with 8\%) assistant professors and lecturers; 
total sample of the study was nine hundred and fifty seven (967) from nine (9) public and four (04) private sector universities (45\%) of Khyber Pakhtunkhwa (Gay \& Mills, 2011).

\section{Data Collection Tools}

Questionnaires and in-depth interview were used as research instruments to collect data from the concerned participants and informants.

\section{Data Analysis}

\section{R.Q.1:- What are authentic leadership attributes of educational leaders at university} level?

\section{Table 1}

\section{Self-Awareness among university leaders}

\begin{tabular}{llll}
\hline S. N & Statements & M & Std D \\
\hline 1 & I can list my three greatest weak points. & 4.57 & .669 \\
2 & I can list my three greatest strong points. & 4.87 & .649 \\
3 & I seek feedback as a way of understanding who I really am as a person. & 4.66 & .666 \\
4 & I accept the feelings I have about myself. & 4.76 & .465 \\
5 & I consider myself answerable to all. & 4.77 & .810 \\
6 & I remain I am aware of my own loopholes and openly discuss with & & \\
& followers. & 4.56 & .667 \\
& Overall & 4.59 & 0.65 \\
\hline
\end{tabular}

Table 1 shows that respondents revealed "strongly agreed" with the all statements of self-awareness construct having mean scores 4.57, 4.87, 4.76, 4.77, 4.66 and 4.56 which come in the (Range from 4.51 to 5.00) among leaders. The overall mean score 4.59 comes in the range (4.51 - 5.00), and it shows that all the respondents strongly agreed with the construct of self-awareness of authentic leadership. The mean scores further show that the most of the leaders at university level are self-aware and have the attribute of self-awareness, which is the prime component of authentic leadership.

However, all the STD deviation scores reflect that all the respondents have convergence in their opinions about the statements of self-awareness

\section{Table 2}

Relational Transparency among university leaders

\begin{tabular}{llll}
\hline S. No & Statements & M & Std D \\
\hline 1 & I openly share my feelings with others. & 4.81 & .419 \\
2 & I let others know who I truly am as a person. & 4.73 & .440
\end{tabular}


3 I rarely present a "false" front to others.

$3.54 \quad .720$

$4 \quad$ I confess to others for my mistakes.

$4.53 \quad .681$

5 I almost always consult with my team before decision-making.

$4.83 \quad .388$

6 I keep positive relations with followers.

$4.26 \quad .440$

Overall

$4.45 \quad .514$

Table 2 indicates that respondents showed "strongly agreed" (Range from 4.53 to 4.83) with the four statements. Statements "I rarely present a "false" front to others." and "I keep positive relations with followers." have the mean scores " 3.54 " and "4.26" which demonstrate that the respondents agreed with two statements. The overall mean score 4.45 follows the range $(3.51$ - 4.50) shows that all the respondents agreed with all the statements. The mean scores further show that the leaders at university level have transparency in their relationship with followers and have the attribute of relational transparency, which is the key component of authentic leadership. However, most of the STD scores reflect that all the respondents are unanimous in their opinions about the statements.

\section{Table 3}

Balance Processing of Information among university leaders and followers

\begin{tabular}{llll}
\hline S. No & Statements & M & Std D \\
\hline 1 & I seek others' opinions before making up my own mind. & 4.56 & .685 \\
2 & I listen closely to the ideas of those who disagree with me. & 4.74 & .539 \\
3 & I do not emphasize my own point of view at the expense of others. & 4.55 & .677 \\
4 & I listen carefully to the ideas of others before making decisions. & 3.51 & .751 \\
5 & My followers feel I am genuinely interested in serving them. & 3.71 & .847 \\
6 & I share my information with followers. & 4.15 & .575 \\
& Overall & 4.20 & .679 \\
\hline
\end{tabular}

Table 3 points that respondents show "strongly agreed" (Range from 4.55 to 4.74) that come in range of strongly agreed (4.51 to 5.00) with the three statements and "agreed" (Ranged from 3.51 to 4.15 ) which come in the range (3.50 to 4.50). The overall mean score 4.20 move toward the range $(3.51-4.50)$ shows that all the respondents agreed with all the statements. The mean scores further show that the leaders at university level have the balance processing of information within the outskirts of the university and have the quality of balance processing of information, which is an important component of authentic leadership. 
However, the standard deviation scores reflect that all the respondents are undivided in their opinions about the statements of balance processing.

\section{Table 4}

Ethical perspective among university leaders

\begin{tabular}{lllc}
\hline S. No & Statements & M & Std D \\
\hline 1 & My actions reflect my core values. & 4.66 & .668 \\
2 & I do not allow group pressure to control me. & 4.67 & .660 \\
3 & Other people know where I stand on controversial issues. & 4.70 & .638 \\
4 & My moral standards guide me what I see to do as a leader. & 4.70 & .638 \\
5 & I deal ethically with my followers. & 4.59 & .662 \\
6 & I look forward to creating genuine relationship through my & 4.59 & .662 \\
& association at work. & & \\
& Overall & 4.65 & 0.65 \\
\hline
\end{tabular}

Table 4 describes that respondents are "strongly agreed" (Range from 4.59 to 4.70 ) with the all six statements. The overall mean score 4.65 follows the range $(4.51-5.00)$ displays that all the respondents strongly agreed with all the statements. The mean scores further show that the leaders at university level are ethically strong and have the attribute of ethical perspective, which is a major component of authentic leadership. However, most of the standard deviation scores reflect that all the respondents are exclusive in their opinions about the statements ethical perspective.

\section{Table 5}

Positive psychological capital among university leaders

\begin{tabular}{llcc}
\hline S. No & Statements & M & Std D \\
\hline 1 & I am optimistic in my performance as role model for my followers. & 4.59 & .662 \\
2 & I share common vision with my associates. & 4.49 & .809 \\
3 & I encourage my co-workers when facing difficulties. & 4.49 & .809 \\
4 & I try to become a model of authentic leadership attributes. & 4.48 & .809 \\
5 & The actions I take are always linked with my values. & 4.49 & .809 \\
6 & I am resilient and won't be unhappy for long. & 4.68 & .646 \\
& Overall & 4.53 & 0.75 \\
\hline
\end{tabular}

Table 5 refers to that respondents show "agreed" (Range from 4.48 to 4.49) to the four statements. Statements "I am optimistic in my performance as role model for my 
followers." and "I am resilient and won't be unhappy for long" having the mean scores "4.59" and "4.68" which express that the respondents strongly agreed with these two statements. The overall mean score 4.53 emanates in the range (4.51 - 5.00) shows that all the respondents strongly agreed to all the statements. The mean scores further show that the leaders at university level are hopeful, self-efficacious, resilient and optimistic; and have the attribute of positive psychological capital, which is a most important component of authentic leadership. However, the standard deviation scores reflect that all the respondents have the similar opinions about the statements of positive psychological capita

\section{Table 6}

Followers' authentic leadership development among university teachers

\begin{tabular}{llll}
\hline S. No & Statements & M & Std D \\
\hline 1 & I receive recognition from the leader for doing good work. & 4.13 & 0.72 \\
2 & I feel that my fellow workers are committed to doing good quality & & \\
& work because of authentic leader. & & 0.73 \\
3 & The leader makes me feel that my job is important for the well- & 4.37 & 0.66 \\
& being of others. & 4.55 & 0.67 \\
4 & I am satisfied what I am doing for the others, & 3.94 & 0.87 \\
5 & I am contented what I am receiving for my job. & 4.24 & 0.62 \\
6 & I receive recognition from the leader for doing good work. & 4.23 & 0.71 \\
\hline
\end{tabular}

Table 6 mentions that respondents "agreed" (Range from 3.94 to 4.37) with five the statements as come in the range (3.51 to 4.50). Statements "My job inspires me" having the mean scores " 4.55 " which takes place in the range (4.50-5.00) expresses that the respondents showed strongly agreed. The overall mean score 4.23 emanates in the range (3.51 - 4.50) illustrates that all the respondents agreed to all the statements of followers authentic leadership development. The mean scores further show that the leaders at university level have the abilities to engage followers in the best of their activities for the development of the organization and well-being of the human resources, and they believe that followers' authentic leadership development is the best construct for the organizational development and is a necessary element for the professional development of the teachers and other followers. However, the standard deviation scores reflect that all the respondents have the alike opinions about the statements of followers' authentic leadership development. 


\section{Table 7}

Pearson Product Moment Correlations between self-awareness and followers authentic leadership development

\begin{tabular}{|c|c|c|c|c|}
\hline & orrelations & SA & JS & \\
\hline \multirow{3}{*}{$\begin{array}{l}\text { Self- } \\
\text { awareness }\end{array}$} & Pearson Correlation & - & $.388^{* * *}$ & \\
\hline & Sig. (2-tailed) & & .000 & \\
\hline & $\mathrm{N}$ & & 967 & \\
\hline $\begin{array}{l}\text { Followers } \\
\text { authentic }\end{array}$ & Pearson Correlation & & & $.912^{*}$ \\
\hline leadership & Sig. (2-tailed) & & & .000 \\
\hline development & $\mathrm{N}$ & & & 967 \\
\hline
\end{tabular}

Table 7 illustrates that the self-awareness which is the first construct of authentic leadership has the average correlation for followers' authentic leadership development ( $\mathrm{r}$ value .388) which is significant at .000

\section{Table 8}

Pearson Product Moment Correlations between relational transparency and followers' authentic leadership development

Correlations

\begin{tabular}{|c|c|c|c|}
\hline \multirow{3}{*}{$\begin{array}{l}\text { Relational } \\
\text { Transparency }\end{array}$} & Pearson Correlation & $-.115^{3}$ & \\
\hline & Sig. (2-tailed) & .000 & \\
\hline & $\mathrm{N}$ & 967 & \\
\hline \multirow{3}{*}{$\begin{array}{l}\text { classroom } \\
\text { management }\end{array}$} & Pearson Correlation & - & $.912^{* *}$ \\
\hline & Sig. (2-tailed) & & .000 \\
\hline & $\mathrm{N}$ & & 967 \\
\hline
\end{tabular}

Table 8 illustrates that the relational transparency which is the most important construct of authentic leadership has the highest correlation for followers' authentic leadership development ( $\mathrm{r}$ value .115) which is significant at .000 
Table 9

Pearson Product Moment Correlations between balance processing and followers authentic leadership development

Correlations BP JS

\begin{tabular}{llcc}
\hline Balance & Pearson Correlation & $.129^{* * *}$ & \\
Processing & Sig. (2-tailed) & .000 & \\
& $\mathrm{~N}$ & 967 & \\
Followers $\quad$ authentic & Pearson Correlation & $.912^{* *}$ \\
leadership development & $\mathrm{N}$ & .000 \\
& $\mathrm{~N}$ & 967 \\
$* *$. Correlation is significant at the 0.01 level (2-tailed). & \\
\hline
\end{tabular}

Table 9 illustrates that the balance processing, which is the third construct of authentic leadership, has the highest correlation for followers' authentic leadership development ( $\mathrm{r}$ value .129) which is significant at .000

\section{Table 10}

Pearson Product Moment Correlations between ethical perspective and followers' authentic leadership development

\begin{tabular}{|c|c|c|c|c|}
\hline \multicolumn{2}{|r|}{ Correlations } & $\mathrm{EP}$ & JS & \\
\hline \multirow{3}{*}{$\begin{array}{l}\text { Ethical } \\
\text { Perspective }\end{array}$} & Pearson Correlation & - & $.177^{* *}$ & \\
\hline & Sig. (2-tailed) & & .000 & \\
\hline & $\mathrm{N}$ & & 967 & \\
\hline Followers & authenticPearson Correlation & & - & $.912^{* *}$ \\
\hline leadership & Sig. (2-tailed) & & & .000 \\
\hline development & $\mathrm{N}$ & & & 967 \\
\hline
\end{tabular}

The above table illustrates that the ethical perspective, the fourth construct of authentic leadership, has the highest correlation for followers' authentic leadership development ( $\mathrm{r}$ value .177) which is significant at .000

\section{Table 11}

Pearson Product Moment Correlations between positive psychological capital and followers' authentic leadership development 


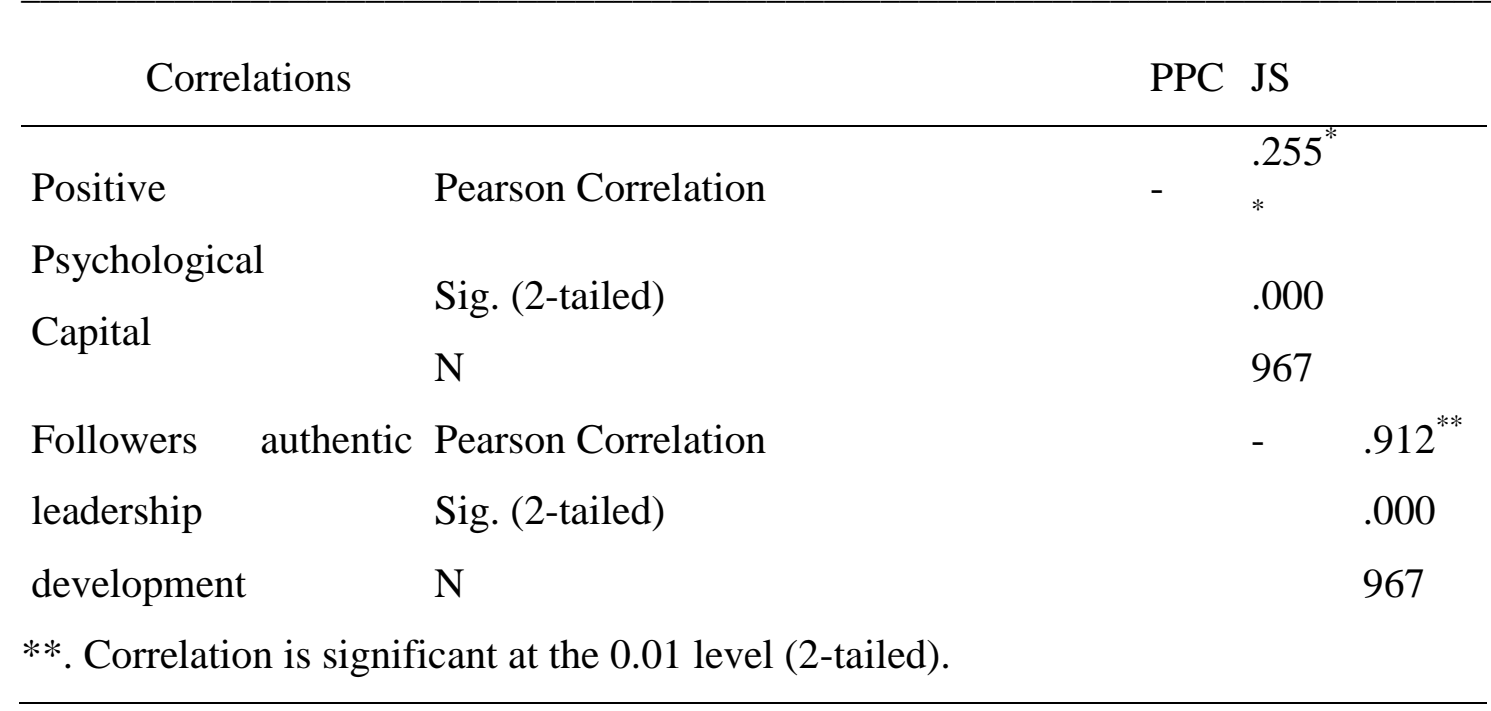

The above table illustrates that the ethical perspective, the construct of authentic leadership, has the highest correlation for followers' authentic leadership development (r value .255) which is significant at .000

\section{Table 12}

Pearson Product Moment Correlations between authentic leadership attributes and followers authentic leadership development

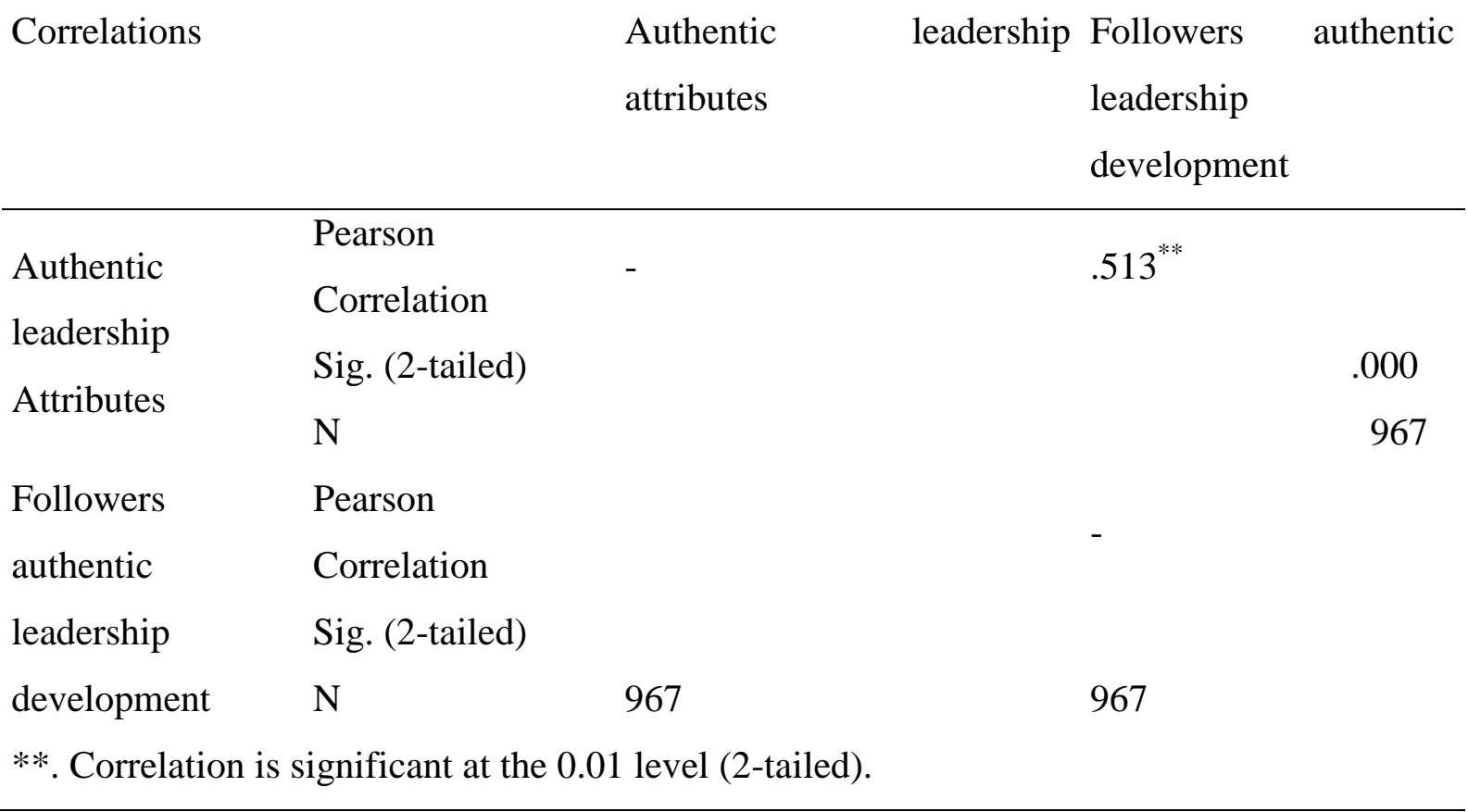

Medium positive correlation between the two variables, $r=.426, n=967, P<.000$, not as much of .05 indicating the statistical significance of the results. Cohen (1988) suggests the following guidelines: small correlation ( $\mathrm{r}=.10$ to .29$)$ medium correlation ( $\mathrm{r}=.30$ to .49 ) large correlation ( $\mathrm{r}=.50$ to 1.0 ) (pp.79-81). In the light of this suggestion, there is medium 
correlation ( $\mathrm{r}=.426)$ between authentic leadership attributes and followers authentic leadership development.

\section{Table 13}

Sector-wise correlation between authentic leadership attributes and followers authentic leadership development in public and private sectors

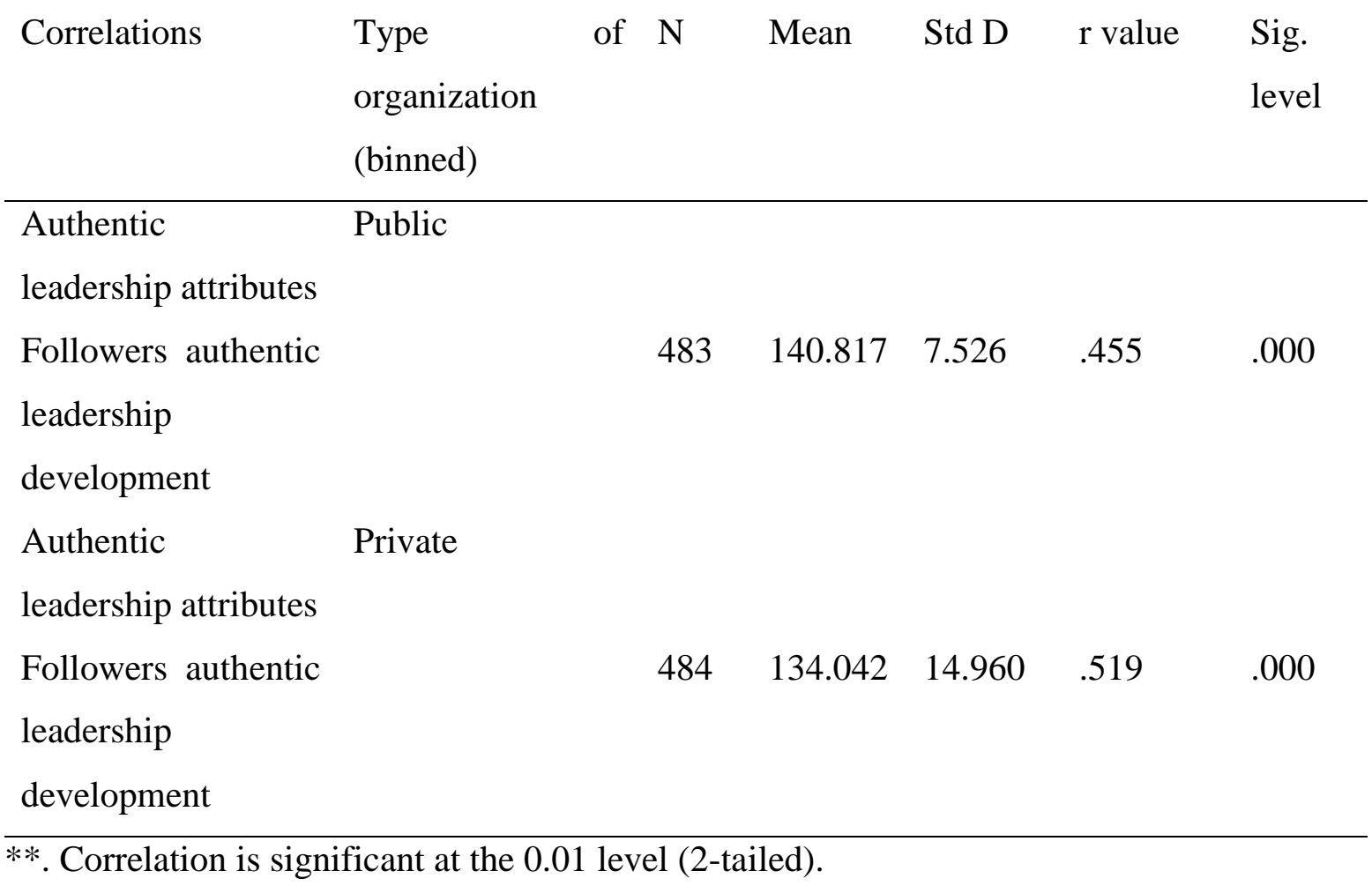

Table 13 illustrates the mean, STD deviation, Pearson correlations and significance of the authentic leadership attributes and followers' authentic leadership development from sector-wise perspective. The mean score of the authentic leadership attributes and followers' authentic leadership development in public and private sector universities was 140.8170 and 134.0424 with standard deviation of 7.52612 and 14.96052. The $\mathrm{r}$ value between authentic leadership attributes and followers' authentic leadership development in public sector universities is $(\mathrm{r}=.355)$ showing medium relationship which is highly significant as shown by the significant level (.000). The $\mathrm{r}$ value between authentic leadership attributes and followers' authentic leadership development in private sector universities is $(r=.519)$ which is indicative of large correlations as suggested by Cohen (1988) that small correlation ranges from (.10 to .29$)$ medium correlation (.30 to .49) and large correlation (.50 to 1.0) which is highly significant as shown by the significant level (.000). These values show that relationship between authentic leadership attributes and followers' authentic leadership development in private sector universities is higher than public sector universities. 


\section{Findings}

Major findings of the study were;

Major findings of the study were;

1. The overall mean scores $(4.57,4.45,4.20,4.65$ and 5.53) showed authentic leadership attributes of university leaders (Table 1, 2, 3, 4 \& 5).

2. The cumulative mean score (4.38) reflected followers authentic leadership development of teachers (table 4.6).

3. The $\mathrm{r}$ values $(.398, .125, .139, .187$ and .265) which were significant at .000 showed significant positive correlations of authentic leadership attributes with followers' authentic leadership development (table 7, 8, 9, $10 \& 11$ ).

4. The $\mathrm{r}$ value (.513) which was significant at .000 showed significant large correlations between authentic leadership and followers' authentic leadership development at university level. (Table 12)

5. The $\mathrm{r}$ value (.455) which was significant at .000 showed a significant average correlation in public sector universities between authentic leadership and organizational development at university level. (Table 13)

6. The $r$ value (.519) which was significant at .000 showed a significant large correlation in private sector universities between authentic leadership and organizational development at university level. (Table 13)

7. From qualitative data, the process and attributes which transform followers into authentic leaders that how a followers becomes authentic leader was also drawn. The major themes of authentic leadership were those attributes which guarantee transforming followers into authentic leaders that self-awareness, relational transparency, ethical perspective, balance processing of information and positive psychological capital.

\section{Discussions}

This study adds to the authentic leadership literature by documenting empirical support of relations between authentic leadership and organizational development, and particularly, teacher professional development- work engagement, followers' authentic leadership development, professional development trainings, and leader followers' interaction and followers' authentic leadership development. All hypothesized relations were supported by the data. As expected, authentic leadership attributes self-awareness (Walumbwa et al., 2008), relational transparency (Walumbwa et al. , 2008; ClappSmith et al., 2009), ethical perspective (Walumbwa et al., 2008; Spillane, 2005; Branson, 2010) and balance processing information were significantly positively related to work engagement. Banks, McCauley, 
Gardner, \& Guler, (2016); Miralles, Navarro \& Unger (2015);Rana (2015), followers' authentic leadership development (Lee \& Sabharwal, 2016), professional development trainings, and leader followers interaction (Qu, Janssen \& Shi, 2015; Baker, Anthony \& Stites-Doe, 2015) and followers' authentic leadership development (Walumbwa et al., 2008). This finding was consistent with Walumbwa et al. (2008), who found self-awareness, relational transparency, ethical perspective and balance processing of information as the constructs of authentic leadership.

Positive psychological capital attribute of authentic leadership was found to be significantly positively related to work engagement work engagement, followers' authentic leadership development, professional development trainings, and leader followers' interaction and followers' authentic leadership development. This finding is in line with previous research of Rego et al. (2013).

This study suggests that authentic leadership (AL) is significantly related to organizational development which is in line with the studies of Hwang and Lee (2015), Gardner et al. (2011) and Walumbwa et al. (2008) who coined self-knowledge and selfawareness as integral components of AL in accord with Hamachek (2000) and Lux (2012) who emphasized that followers improve more self-awareness as their authentic leadership attributes progress. High authentic leaders are, therefore, able to appropriately transform their behaviors for attaining the desired organizational goals.

Earlier empirical studies have related AL to both attitudinal (Laschinger, Wong, \& Grau, 2013; Leroy, Palanski, \& Simons, 2012) and behavioral outcomes (Hannah, Walumbwa, \& Fry, 2011a; Leroy, Anseel, Gardner, \& Sels, 2015). Empirical studies suggest that when leaders are aware of their moral standards and act upon such principles, they are more likely to gain higher levels of performance and assist others to get done the same (Ryan \& Deci, 2001). Followers tend to express greater satisfaction with their leader when the leader involves in authentic actions, and this satisfaction is likely to link to a growth in followers' authentic leadership development (Jensen \& Luthans, 2006).

Leaders who are professed to be more moral and make righteous decisions will be professed as caring more about their followers (Brown \& Treviño, 2006). Furthermore, AL has got a strong relation to enhanced task performance (Leroy et al., 2015) and performance at both the group and organizational levels (Hannah et al., 2011a), in part, because persons, who are authentic, are able to efficiently use balanced processing of information and establish consistency between their sayings and actions (Walumbwa et al., 2008). Gardner et al. (2005) 
present a "conceptual framework for authentic leader and followers' development", in which the development of followership is the result of Authentic Leadership.

"a pattern of leader behavior that draws upon and promotes both positive psychological capacities and a positive ethical climate, to foster greater selfawareness, an internalized moral perspective, balanced processing of information, and relational transparency on the part of leaders working with followers, fostering positive self-development" (Rego, Vitória, Magalhães, Ribeiro, \& Cunha, 2013, p. $62)$.

Harter (2005) presents a catalogue of psychological paybacks for being authentic, namely; higher self-esteem, more positive effect and more futuristic optimism. Mostly, authentic leaders are more salient due to their inherent features and they influence their followers by their authentic deeds and positive relation and by this strong constructive relation with followers, authentic leaders surpass authenticity (Gardner et al., 2005).

Liborius (2014) found that truth, meekness, mercy, concern, awareness and gratefulness towards followers positively correlated with followers' willingness to engage with their leader, and positively correlated with organizational development which favors the findings of this study.

Leader confidence or effectiveness is recognized in the AL model as a positive psychological capacity possessed by authentic leaders and being helpful for goal attainment (Luthans, Youssef, \& Avolio, 2007). Authentic leadership is reciprocal (Begley, 2006). These empirical works supports the finding of this study.

Authentic leadership is a process in which leaders and followers assist each other to make progress to a higher level of morale and motivation. It produces significant transformation in the life of individuals and organization, discernment and principles are reshaped, prospects and ambitions of followers are changed, leader's personality, is valued, role model is made for ethical development, vision is energized and goals are faced (Kotlyar \& Karakowsky, 2007).

Narrative, reflection and other modes focus leaders to investigate the origins of their values, actions, and assumptions, and thus be better positioned to encourage and empower the leadership of followers (Chávez \& Sanlo, 2013).

Relational model is another strength which focus on the development of leaders and followers and that is not leader-centric, but giving followers their share of the power and 
responsibility in the leadership of a particular organization and the development of its members rather than just being resources to a production end (Dugan \& Komives, 2010).

\section{Recommendations}

In the light of findings and conclusions of the study, following recommendations were made.

Authentic Leadership must be the theoretical lens through which all educational leadership development is perceived and developed. Since Begley (2006, p. 570) defines that Authentic Leadership "is a metaphor for professionally effective, ethically sound, and consciously reflective practices in educational administration", therefore, it is time for universities to encourage, motivate, progress and develop authentic leaders. Organizations in our country desires educational leaders who, while at the forward-facing line of defense, are grooming and educating a new generation through authentic leadership, as it is considered the architect of morality which are not guaranteed by position and prestige, but who lead by the attributes of Authentic Leadership. In reality, what these researchers actually learned from the study is that followers wish for Authentic Leadership in their universities.

Great shortage of research is found on Authentic Leadership and its relationships to any factor in the educational system of our country, therefore, the field is ready for ploughing. With Authentic Leadership as a theoretical framework for research, it is the informants' unanimous conviction that call for an innovative leadership approach with a purpose to restoring "confidence, hope, optimism, resiliency, and meaningfulness" in leadership practices (Avolio et al., 2004, p. 3) can and should start now. Since the results of this study support the idea that Authentic Leadership is a desirable leadership construct in this country, then further empirical research may be conducted in the field of education aiming at growing and developing authentic leaders, preparing them to meet the challenges of leading universities. Authentic leadership is still in the early stages of development, and much empirical research is looked-for to advocate the rich theoretical foundations of this theory. The range of this study concentrated largely on self-awareness as the first component of Authentic Leadership and the current research on enhancing current leadership practices. On the other hand, more tools are required to be exposed or advanced to meet the other aspects of an internalized moral perspective, balanced processing of information, positive psychological capital and relational transparency.

In terms of organizational development, Authentic Leadership, when demonstrated, has been shown to make available a firm underpinning for proper and viable organizational development (Luthans \& Avolio, 2003). Begley (2006) tackled the matter as it concerns to 
educational leaders, who, he said, must engage the university community regarding all relevant problems. This notion was further confirmed by the teachers in this study, who communicated their pleasure and yearning to work in an environment where Authentic Leadership is demonstrated. Since educational leadership is thought to present values and an ethical attempt, and further, since Mehmood, Nawab, and Hamstra (2016) highlighted that leadership can be advanced through formal training, further research must face this requirement for training. And lastly, there has been a recent move in Authentic Leadership research toward the development of followers (Avolio \& Walumbwa, 2014). Additionally, study on followers' development could shed light on how teachers might be trained in Authentic Leadership attributes in order to improve organizational development (Harvey, Martinko, \& Gardner, 2006).

In the near future, methodological correctness will likely maintain its salience. It would be expected that humanistic and aesthetic values will be highlighted /neglected in research in the face of issues of social justice and pragmatism. Capitalistic elements related to the costs of education and the ways in which the education system provides a suitable labor force for the nation's economy will likely be emphasized. Whatever work is done or neglected, research must refresh intellect.

It is suggested that more leadership opportunities be provided for teachers, with the intention also to provide greater incentives to the professional.

It may be well to conduct research study on the authentic leadership at primary level, secondary level and college level both at private and public sectors as these areas are in great need of authentic leadership because these sectors suffered a lot due to unethical attitude of the leaders.

It becomes incumbent upon each and every researcher, leader and followers, who seeks the dignity and bliss of authentic leadership, to regulate his /her life according to the valuable constructs (attributes) of authentic leadership; as not accumulated wealth ( by hook or crook) but righteousness (authentic leadership attributes) attains the happy end; the gift of Nature and the solace of mind and soul come from adopting authentic leadership attributes; as authentic leadership creates purity, harmony, balance and transparency; and evil is doomed to perish. Authentic leadership is a guide and a mercy to men and teaches them wisdom- the path of Golden Mean-pure life.

It is concluded from the interviews that theoretically leaders are very strong but in practice they are lagging behind. One interviewee remarked "(HAM GUFTAAR K HERO 
HAN LAKEN KIRDAAR K ZERO). It means that speech-wise we are heroes but characterwise we are zeroes." Therefore it is recommended that all leaders and teachers must work in disciplined ranks to repel evil. They must choose between Good and evil, with their consequences in the coming life. If they did well, they did well for themselves; if they did evil, they did it against themselves.

\section{References}

Avolio, B., Luthans, F., \& Walumbwa, F. O. (2004). Authentic leadership: Theory building for veritable sustained performance. Working paper. Lincoln: Gallup Leadership Institute, University of Nebraska. BIBLIOGRAPHY \ 2057

Humphreys. J. H., Wallace A. Williams Jr. W.A., Clayton. R. \& Novicevic. M. M. (2011). Towards the augmenting role of authenticity: Xenophon as leadership theorist, Management \& Organizational History, 6(2), 183-207.

Hwang, Y. K., \& Lee, C. S. (2015, April). Structural Relationship between Authentic Leadership, Organizational Communication, Organizational Effectiveness, and Psychological Capital of Office W orkers. Indian Journal of Science and Technology, 8(57), 292-298. Retrieved February 11, 2016

BIBLIOGRAPHY \l 1033 Ilies, R., Morgeson, F. P., \& Nahrgang, J. D. (2005). Authentic Leadership and the eudemoic well-being: understanding leader-follower outcomes. Leadership Quarterly 16 ,343-394

Jensen, S. M., \& Luthans, F. (2006). Entrepreneurs as authentic leaders: Impact on employees' attitudes. Leadership \& Organization Development Journal, 27(8), 646666.

Jones, S. R., Kim, Y. C., \& Skendall, K. C. (2012). (Re-) Framing Authenticity: Considering Multiple Social Identities Using Auto ethnographic and Intersectional Approaches. The Journal of Higher Education, 83(5), 698-724.

Kernis, M. H. (2003). Toward a conceptualization of optimal self-esteem. Psychological Inquiry, 14, 1-26.

Kotlyar, I., \& Karakowsky, L. (2007). Falling Over Ourselves to Follow the Leader. Journal of Leadership \& Organizational Studies, 14(1), 38-49.

Leroy, H., Anseel, F., Gardner, W. L., \& Sels, L. (2015). Authentic leadership, authentic followership, basic need satisfaction, and work role performance: A cross-level study. Journal of Management, 41(6), 1677-1697. 
Leroy, H., Palanski, M. E. \& Simons, T. (2012). Authentic leadership and behavioral integrity as drivers of follower commitment and performance. Journal of Business Ethics, 107(3), 255-264.

Liborius, P. (2014). Who is worthy of being followed? The impact of leaders' character and the moderating role of followers' personality. The Journal of psychology, 148(3), 347-385.

Luthans, F., \& Avolio, B. J. (2003). Authentic leadership development. (K. S. Cameron, J. E. Dutton, \& R. E. Quinn, Eds.), San Francisco, USA: Berrett Koehler.

Luthans, F., Luthans, K.W., Luthans, B. C., (2004). Positive psychological capital: beyond human and social capitale, Business Horizons, Justice Owusu-Bempah International Journal of Social Science Research 74 (47), 45-50.

Luthan, F., \& Yousaf, C. M. (2004). Human social and positive psychological capital management: investing in people for competitive advantage. Organizational Dynamics 33, 143-160.

Luthans, F., Youssef, C.M., Avolio, B.J. (2007). Psychological Capital: developing the human competitive edge. Oxford University Press, Oxford.

Lux, A. A. (2012). Follower's Perceptions of Authentic Leadership and their Job Satisfaction: Impact of Ethnicity. Unpublished master's thesis, Auckland University of Technology, School of Business management.

Mehmood, Q., Nawab, S., \& Hamstra, M. R. (2016). Does Authentic Leadership Predict Employee Work Engagement and In-Role Performance?. Journal of Personnel Psychology.

Miralles, C., Navarro, J., \& Unger, D. (2015). Daily work events and state work engagement: The mediating role of affect/Eventos diarios y work engagement: El rol mediador del afecto. Revista de Psicología Social, 30(2), 264-294.

Northouse, P. G. (2014). Introduction to leadership: Concepts and practice. Sage Publications.

Padilla, A., Hogan, R., \& Kaiser, R. B. (2007). The toxic triangle: Destructive leaders, susceptible followers, and conducive environments. The Leadership Quarterly, 18(3), 176-194.

Pirannejad, A. (2013) authentic leadership style required in university management, case study of Payam Noor University, Tehran, Alborz, the Routledge Qu, 
R., Janssen, O., \& Shi, K. (2015). Transformational leadership and follower creativity: The mediating role of follower relational identification and the moderating role of leader creativity expectations. The Leadership Quarterly, 26(2), 286-299.

Rana, S. (2015). High-involvement work practices and employee engagement. Human Resource Development International, 18(3), 308-316.

Rego, A. Vitória, A. Magalhães, A, Ribeiro, N. \& e Cunha, M. P. (2013). “Are authentic leaders associated with more virtuous, committed and potent teams?" The Leadership Quarterly, 24(1), 61-79.

Shamir, B. \& Eilam, G. (2005). What's your story? A Life-stories approach to Authentic Leadership Development. Leadership Quarterly 16, 395-417.

Sparrowe, R. T. (2005). Authentic leadership and the narrative self. The Leadership Quarterly, 16, 419-439.

Tapara, P. L. (2011). Authentic leadership: organizational outcomes and leader and follower development: a thesis presented in partial fulfilment of the requirements for the degree of Master of Arts in Psychology at Massey University, Albany, New Zealand (Doctoral dissertation, Massey University).

Walumbwa, F. O., Avolio, B. J., Gardner, W. L., Wernsing, T. S., \& Peterson, S. J. (2008). Authentic leadership: Development and validation of a theory-based measure. Journal of management, 34(1), 89-126.

Walumbwa, F. O., Wang, P., Wang, H., Schaubroeck, J., \& Avolio, B. J. (2010). Retracted: Psychological processes linking authentic leadership to follower behaviors. The Leadership Quarterly, 21(5), 901-914.

Walumbwa, F. O., Peterson, S. J., Avolio, B. J., \& Hartnell, C. A. (2010). An investigation of the relationships among leader and follower psychological capital, service climate, and job performance. Personnel Psychology, 63(4), 937-963.

Walumbwa, F. O., Luthans, F., Avey, J. B., \& Oke, A. (2011). Retracted: Authentically leading groups: The mediating role of collective psychological capital and trust. Journal of organizational behaviour, 32(1), 4-24.

Wang, H., Sui, Y., Luthans, F., Wang, D., \& Wu, Y. (2014). Impact of authentic leadership on performance: Role of followers' positive psychological capital and relational processes. Journal of Organizational Behavior, 35(1), 5-21.

Watts, D. (2015). True North: Becoming an Authentic Leader by Bill George, Organization Management Journal, 12(4), 251-252 